\title{
Liberalismos e educação. Ou por que o Brasil não podia ir além de Mandeville*
}

\author{
Alceu Ravanello Ferraro
}

Universidade Federal do Rio Grande do Sul, Programa de Pós-Graduação em Educação

\section{Introdução}

O objetivo deste trabalho é enfrentar a questão da relação entre liberalismo e educação. Na realidade, entre alguns liberalismos do século XVIII e a educação escolar. Esse foco aponta também para a relação entre iluminismos e educação escolar.

Parto do fato histórico inegável de que aquilo que hoje se conhece como escola é produto e, ao mesmo tempo, elemento constituinte da sociedade burguesa que se veio formando desde a Baixa Idade Média, isto é, desde a travessia do ano mil. Já na Idade Moderna, mais especificamente a partir da segunda metade do século XVII, e tendo em John Locke seu mito fundador, ${ }^{1}$ o liberalismo passou a constituir-se na ideologia da burguesia em ascensão e do modo de produção capitalista em

* Trabalho desenvolvido dentro de projeto de pesquisa apoiado pelo CNPq.

${ }^{1}$ Ver sobre isso Mikeël Garandeau (1998, p. 47), o qual observa: "Com a condição de se precisar que se trata em grande parte de um mito, sustentado tanto pelos liberais quanto pelos seus críticos marxistas”. expansão. O Iluminismo, por sua vez, é o pensamento filosófico que caracteriza e anima o período das grandes revoluções do século XVIII, que acabaram por alçar a burguesia como classe social ao domínio econômico e, por fim, ao domínio político e cultural.

Foram dois os motivos que me levaram a esta investigação. O primeiro foi a lentidão com que o Brasil imperial enfrentou a questão da educação popular, sem evidência maior, também, de que o advento da República tenha significado mudança relevante nesse campo. O segundo motivo foi a tomada de conhecimento do teor dos debates sobre o voto dos analfabetos travados no Brasil entre a grande maioria liberal e a pequena minoria, também ela liberal, que compunham a Câmara dos Deputados nos anos de 1878 a 1880, justamente quando a Monarquia já se encaminhava para o ocaso. A expectativa é que tal estudo possa jogar alguma luz sobre a relação que o tipo de liberalismo dominante manteve com a educação popular no Brasil no Segundo Reinado, com destaque para o período da reforma eleitoral de 1878 a 1881. É claro, com o olhar voltado para este início do século XXI!

Quanto à vagareza da ação pública em assunto de educação popular, basta lembrar o quadro sombrio 
do estado da escolarização no Primeiro Reinado, na Regência e no Segundo Reinado adentro descrito por Primitivo Moacyr (1938). O autor relata que, na abertura da Assembleia Constituinte Legislativa em 1823, o imperador dom Pedro I afirmara haver promovido os estudos públicos tanto quanto era possível, recomendando consideração para o assunto. O que se seguiu à Proclamação da Independência e à Carta constitucional de 1924 é assim descrito por Moacyr:

\footnotetext{
Na abertura da Assembleia Geral Legislativa, 1826, a primeira após a promulgação da Carta Constitucional de 1824, não voltou o Imperador a pedir para o ensino público a 'suma consideração' de três anos atrás. Durante o período da Regência e das duas primeiras décadas da maioridade, o mesmo silêncio sobre a instrução, apesar dos vivos debates parlamentares de 1846 e 1847, e das queixas dos ministros do Império, em seus relatórios, sobre a deficiência de prédios escolares, de método e, sobretudo, da miséria em que se debatiam os mestres. Alguns insistiam pela criação de universidades. (Moacyr, 1838, p. 662)
}

No que se refere aos debates parlamentares travados nos anos de 1878 a 1880 a propósito dos projetos de reforma eleitoral, basta lembrar aqui alguns fatos. Quando, nos referidos debates, o deputado Rui Barbosa defendia a adoção do censo literário (comprovação de saber ler e escrever) para poder votar, um deputado perguntava: "Onde estão essas ondas de instrução derramadas pelo país para exigirmos essa condição pedantesca de saber ler e escrever?” (apud Holanda, 1977, p. 199). E Holanda comenta: “Os 'Oh Oh' que provocou a 'condição pedantesca’ mostram como os legisladores de 1879 tinham mais medo do votante analfabeto do que os constitucionalistas de 1824" (Holanda, 1977, p. 199). Em síntese: analfabeto não pode votar, mesmo que não haja escolas para o povo se alfabetizar. No meu entendimento, o objetivo perseguido pela maioria liberal - ou melhor, pelo tipo de liberalismo que imbuía a imensa maioria da Câmara

${ }^{2}$ Nas citações de Primitivo Moacyr a ortografia foi atualizada.
- não era tanto o de excluir os analfabetos do direito de voto quanto o de colocar barreira à participação popular em geral, servindo o analfabetismo generalizado apenas de pretexto legitimador da exclusão do povo da cidadania. Analfabeto, ao tempo da reforma eleitoral levada a termo pela Lei Saraiva de 1881, era praticamente sinônimo de povo.

A questão que essas reflexões foram sugerindo ${ }^{3}$ e que renovo aqui é se o Brasil, um país agrícola, latifundiário e ainda teimosamente escravocrata ao tempo do Segundo Reinado, poderia ter ido além de Mandeville em assunto de educação popular. Fica subentendido que Mandeville representara, na Inglaterra do primeiro quartel do século XVIII, a posição mais conservadora, de medo até, em assunto de educação popular. No Brasil, negar o voto aos analfabetos era um encaminhamento tranquilizador para as elites do final do Império, inclusive para a imensa maioria das consciências liberais que compunham a Câmara dos Deputados dos ministérios Sinimbu e Saraiva nos anos 1878 a 1882, também chamada de Câmara dos Servis.

O movimento de alfabetização e de busca da instrução escolar em geral, que fora retomado com o desenvolvimento do comércio e a urbanização a partir dos séculos XI e XII, teria novo e vigoroso impulso a partir das grandes revoluções da segunda metade do século XVIII: a Revolução Industrial, na Inglaterra, a Independência dos Estados Unidos e a Revolução Francesa. Mas, neste ponto, uma coisa precisa ficar bem clara: o capitalismo e sua ideologia, o liberalismo, mantiveram desde o início uma relação ambígua e até conflituosa com a escola, porquanto esta, se por um lado se afigurava necessária, por outro despertava temor.

Esse esclarecimento é importante para que se possa entender o trato que foi dispensado à educação escolar no Brasil no período imperial e mesmo no republicano. O presente texto limita-se a considerar três figuras típicas que se destacaram na Europa do século XVIII pelas suas posições quanto à escolari-

\footnotetext{
3 Essa questão foi por mim abordada em livro ainda
} inédito. 
zação: Bernard Mandeville, Adam Smith e o Marquês de Condorcet, figuras relativamente pouco lembradas nas disciplinas ditas Fundamentos da Educação.

\section{Bernard Mandeville (1670-1733): povo instruído - povo perigoso}

Bernard Mandeville, nascido e educado em Filosofia e Medicina na Holanda, transferiu-se depois para Londres com o propósito de estudar inglês. Em 1688 ou 1689 decidiu fixar-se na Inglaterra. A Fábula das abelhas, que foi sendo construída por partes no período de 1705 a 1729, é sua obra mais conhecida. Duramente criticada e até abominada por uns, exerceu grande influência, embora raramente reconhecida de forma explícita. O ponto de partida foi o livreto anônimo de 1705 intitulado The Grumbling Hive: or, Knaves Turn'd Honest (A colmeia barulhenta ou a redenção dos trapaceiros). Esquecido por cerca de 10 anos, esse texto reapareceu em 1714 como parte de um livro anônimo intitulado The Fable of the Bees: or, Private Vices, Public Benefits (A fábula das abelhas: ou vícios privados, benefícios públicos), o qual teve grande repercussão, suscitando intenso debate. A obra organizada por F. B. Kaye, aqui utilizada na versão em espanhol, compreende a edição de 1732 para a Parte I e a primeira edição de 1729 para a Parte II. O texto que aqui mais interessa é o Ensaio sobre a Caridade e as Escolas de Caridade, incorporado à Fábula das abelhas na edição de 1723 (Kaye, 2001, p. ix a xxiv).

Começo com breve apanhado do texto da fábula. Uma grande colmeia, repleta de abelhas que viviam no luxo e no conforto, afamada por suas leis e por sua população, constituía-se num grande viveiro das ciências e da indústria. As abelhas não eram escravas da tirania nem eram regidas por louca democracia, mas por reis cujo poder era limitado por leis. Esses insetos viviam como homens, realizando em pequeno todos os atos humanos. Cada parte (cada profissão: das menos conhecidas às dos advogados, dos médicos, dos sacerdotes, dos soldados, dos governantes, dos juízes etc.) estava cheia de vícios, mas o conjunto era um paraíso; os próprios pecados da colmeia contribuíam para a sua grandeza. Mas é vã a felicidade dos mortais! Ignorando os limites da bemaventurança, esses bichos murmurantes não mais se contentaram com seus ministros e governo. Antes, a cada infortúnio, quais criaturas perdidas sem remédio, maldiziam seus políticos, exércitos e frotas, ao grito de "Morram os trapaceiros!", até que finalmente Júpiter, movido de indignação, prometeu libertar da fraude a uivante colmeia. E assim o fez. Nesse mesmo instante, a fraude cessou e todos os corações se encheram de honradez. Foi grande e súbita a mudança. O preço da carne baixou em meia hora em toda a nação. Os tribunais ficaram sem serviço, porque todos passaram a pagar de boa vontade as dívidas, até mesmo aquelas de que os credores se haviam esquecido. Da mesma forma nas demais atividades, mesmo entre os grandes ministros e os pequenos funcionários do rei: todos haviam passado a viver dos seus soldos. Na gloriosa colmeia combinavam agora honradez e comércio. Mas os sóbrios que haviam restado queriam saber não mais como gastar, mas como viver. Na taberna, ao pagar a conta, decidiam não mais voltar. A saciedade matara a indústria. Haviam restado na colmeia tão poucas abelhas que só podiam dar conta da centésima parte frente aos embustes das outras colmeias. Mesmo sem mercenários, lutaram com bravura pelo que era seu, obtendo a coroa da vitória. Mas a que preço: calejadas de tanto trabalho e exercícios, agora consideravam vício o próprio descanso. E, para evitar extravagâncias, repletas de contentamento e honradez, emigraram para um tronco oco (Mandeville, 2001, p. 11-21).

A moral da fábula é clara:

Deixai, pois, de queixar-vos: somente os idiotas se esforçam para fazer de uma grande colmeia uma colmeia honrada. Querer gozar dos benefícios do mundo e ser famosos na guerra e viver com folga, sem grandes vícios, é vã utopia assentada no cérebro. Fraude, luxo e orgulho devem viver enquanto desfrutemos de seus benefícios: a fome é, sem dúvida, uma praga terrível, mas, sem ela, quem prospera ou se alimenta?”. (idem, ibidem, p. 21) ${ }^{4}$

${ }^{4}$ É minha a tradução de todas as citações de Mandeville. 
Para o autor, quando um povo aspira à grandeza, o vício é tão necessário para o Estado como o é a fome para comer. Por isso, “a virtude sozinha não pode fazer com que as nações vivam no esplendor; as que quiserem reviver na Idade de Ouro terão que se libertar da honradez como das bolotas" (idem, ibidem, p. 21).

Segundo Kaye (apud Mandeville, 2001, p. lxvlxxvii), a influência da obra de Mandeville se deu em três campos. Na literatura, a influência foi superficial. No domínio da ética, o impacto foi forte, figurando Mandeville entre os principais promotores do desenvolvimento do utilitarismo moderno. Foi no campo da economia que sua influência mais se destacou (embora raramente reconhecida de forma explícita!), e isso particularmente em dois pontos: "na formulação da famosa teoria da divisão do trabalho, que Adam Smith converteu numa das pedras angulares do pensamento econômico moderno", e "como uma das principais fontes literárias da doutrina do laissezfaire”. Mandeville antecipa, por assim dizer, duas formulações importantes do liberalismo econômico clássico: a noção de divisão de trabalho e a noção de liberdade econômica ou liberalismo econômico. Aliás, muito provavelmente Smith deve a Mandeville esses conceitos de divisão do trabalho e de liberdade econômica, tão centrais em sua obra $A$ riqueza das nações, de 1776.

É sumamente interessante o confronto que Renato Janine Ribeiro faz entre John Locke e Bernard Mandeville. Ribeiro vê em Locke o filósofo público do liberalismo e em Mandeville o filósofo oculto do capitalismo. E esclarece: "Locke produz a ideologia do capitalismo, da qual todo liberal pode orgulhar-se, ao passo que Mandeville revela as suas entranhas". E acrescenta: "Não dá para o capital sair a público elogiando Mandeville. Pegaria mal. Mas ele é quem conta o segredo de uma política e de uma economia que não precisam do bem moral para funcionar bem” (Ribeiro, 2004, p. 2).

Tanto Locke como Mandeville se ocuparam da educação, mas de perspectivas bem diferentes. O olhar

\footnotetext{
${ }^{5}$ Fruto da azinheira.
}

de Locke é pedagógico. Seu texto Some Thoughts Concerning Education (Alguns pensamentos acerca da educação), publicado originalmente em 1693, foi recentemente traduzido para o português e publicado por Avelino da Rosa Oliveira e Gomercindo Ghiggi. ${ }^{6}$ Como dizem os tradutores em sua apresentação, o texto foi “elaborado para servir de instrumento na formação do homem para o 'novo momento' instaurado a partir da revolução burguesa de 1688 na Inglaterra" (1999, p. 147). Trata-se, portanto, de obra pedagógica voltada para a educação da burguesia.

Acontece que, na Inglaterra, paralelamente a esse empenho na educação da burguesia, começara a pensar-se também em escolas para os pobres. Como relata Gertrude Himmelbarb (1988, p. 38), as Escolas de Caridade, surgidas no final do século XVII, "proliferaram rapidamente no primeiro quartel do século XVIII". Elas "se encarregavam das crianças indigentes e órfãs entre as idades de 7 a 14 anos, oferecendolhes comida e roupa, ensinando-as a ler a Bíblia e a escrever o suficiente para copiar uma passagem desta e depois as enviavam a trabalhar como aprendizes ou serventes”. Escolas semelhantes espalhavam-se pela França a cargo dos Irmãos das Escolas Cristãs (os Irmãos Lasallistas), também estas voltadas à educação dos filhos dos pobres.

Pois é das Escolas de Caridade que se ocupou Mandeville. Não para ditar-lhes uma pedagogia, como fizera Locke em relação às escolas para a burguesia, mas para pedir-lhes o fechamento. Seu texto "Ensaio sobre a Caridade e as Escolas de Caridade”, juntado à Fábula das Abelhas em 1723, não é um texto pedagógico, mas um texto político, em que o autor se posiciona contra a ação da Igreja da Inglaterra em favor da instrução dos filhos dos pobres - do povo. Na realidade, na situação de união entre Igreja e Estado, essa ação da Igreja voltada à educação dos pobres se constituía em ação pública, que Mandeville

${ }^{6}$ A referida tradução foi publicada em partes na revista Cadernos de Educação, da Faculdade de Educação da Universidade Federal de Pelotas-RS, a começar pelo número 13, volume 8, de 1999. 
considerava indevida, por contrariar, em sua opinião, o princípio da não-intervenção na colmeia humana. Segundo o autor, as abelhas viviam como homens. Na verdade, era a sociedade que ele concebia como uma colmeia. Aquela, como esta, regida por leis naturais. O princípio da não-intervenção é mera decorrência da concepção que Mandeville tem de sociedade, isto é, do fato de a sociedade ser por ele concebida como natureza - uma colmeia.

Retomando a ideia de "liberalismos", importa estabelecer que Bernard Mandeville expressava a posição liberal mais conservadora em relação à escola popular moderna no final do primeiro quartel do século XVIII. A Inglaterra se encontrava em plena fase manufatureira. A Revolução Industrial teria que aguardar ainda cerca de meio século (a contar do texto em questão, de 1723) para ver seu início. A Mandeville assustava a simples ideia de um povo instruído, que facilmente se poderia transformar em povo insatisfeito. A revolução burguesa na Inglaterra (1688) não contava meio século; estava firmando-se. Despertar o apetite das massas poderia ser perigoso:

Para fazer feliz a sociedade e manter as pessoas contentes, mesmo nas circunstâncias mais humildes, é indispensável que o maior número delas seja, ao mesmo tempo que pobres, também totalmente ignorantes. O saber amplia e multiplica os nossos desejos, e quanto menos coisas um homem ambicione, tanto mais facilmente se lhe poderão satisfazer as necessidades.

Portanto, o bem-estar e a felicidade de todo Estado ou Reino exigem que os conhecimentos da classe pobre trabalhadora se limitem à esfera de suas ocupações e que nunca se estendam (no que se refere às coisas visíveis) para além do que se relaciona com a sua profissão. Quanto mais conhecimento do mundo e das coisas alheias ao seu trabalho ou emprego tenha um pastor, um lavrador ou qualquer outro camponês, tanto mais difícil lhe será suportar com alegria e satisfação as fadigas e as dificuldades de seu ofício. (Mandeville, 2001, p. 190)

Para Mandeville, saber ler e escrever e ter conhecimento da aritmética são coisas indispensáveis para aqueles cujos negócios requerem tais conhecimentos. Entenda-se: para a burguesia. Porém, "onde a subsistência do povo não depende delas, tais artes são muito prejudiciais para o pobre obrigado a ganhar o pão de cada dia mediante sua tarefa diária”. O autor reconhece que um homem que tenha recebido alguma educação poderá até dedicar-se de bom gosto ao cultivo dos campos e "ser tão diligente como o trabalhador mais sujo e laborioso”. Neste caso, porém, "a propriedade que cultiva terá que ser sua, e a avareza, o cuidado de uma família, ou algum outro motivo premente terá que tê-lo compelido a isto". E mais: esse trabalhador, proprietário de sua terra,

\section{[...] nunca será um bom jornaleiro nem servirá a granjeiro algum por uma recompensa miserável; pelo menos, não será tão adequado para este trabalho como o jornaleiro que sempre andou empregado aqui e acolá, que sempre esteve ocupado com o arado e o carro de esterco, sem lembrança de outro modo de vida melhor. (idem, ibidem, p. 191-192, grifo meu)}

Para Mandeville, é o mercado que deve regular a educação, e esta nunca deveria ser gratuita:

\footnotetext{
Eu consideraria a questão de saber ler e escrever como fazemos com a música e a dança: não imporia à sociedade o seu conhecimento, nem o dificultaria; sempre que fosse possível obter alguma vantagem disto, haveria número suficiente de mestres para ensinar; no entanto, não se deve ensinar nada de graça, a não ser na Igreja. (idem, ibidem, p. 197)
}

Para o autor, a maioria da nação deveria ser constituída de "trabalhadores pobres, alheios a tudo o que não seja o seu trabalho", uma vez que "ninguém que possa evitá-lo fará o trabalho sujo e abjeto”. E justifica: "Eu não os censuro; porém todas estas coisas indicam que as pessoas da classe mais baixa sabem demais para ser-nos úteis" (idem, ibidem, p. 201, grifo meu).

Parece que Mandeville está obcecado pela questão de que possa não haver número suficiente de trabalhadores para a grande quantidade de trabalho duro e sujo a se fazer em cada sociedade: "É muito o 
trabalho duro e sujo que é necessário fazer, e há que se resignar à vida dura. Como podemos encontrar melhor solução para remediar a estas necessidades senão recorrendo aos filhos dos pobres? Nada, por certo, é mais adequado para isto” (idem, ibidem, p. 207). Por isso, "quanto menos noção tenha um homem de outra existência melhor, mais contente se sentirá com a sua". Para o autor, essas são coisas inegáveis, embora sua divulgação agrade a poucos (idem, ibidem, p. 207-209).

Para Mandeville, a submissão do povo é coisa inegociável, e a ignorância desempenha papel estratégico na consecução desse objetivo. No seu entendimento, somente a pobreza e a ignorância juntas poderão gerar tal submissão, uma vez que "nenhuma criatura se submete de boa vontade a seus iguais". E acrescenta: "se um cavalo tivesse tanto conhecimento como um homem, eu não teria o menor desejo de ser seu ginete” (idem, ibidem, p. 192).

Está aí esboçada uma verdadeira pedagogia da doma! Mas é necessário fazer justiça: a pedagogia da doma não constituiu exclusividade de Bernard Mandeville. Já em 1500, Pero Vaz de Caminha, em sua carta ao rei de Portugal, referira-se à aplicação dessa pedagogia aos indígenas da terra recém-descoberta: "Tudo se passa como eles querem, para os bem amansar” - escreveu. (in Amado \& Figueiredo, 2001, p. 99). E novamente, em 1786, decorridos pouco mais de 60 anos desde o texto sobre as Escolas de Caridade, o pastor inglês Joseph Townsend retomaria com igual ênfase essa concepção em sua obra A dissertation on the poor laws (Uma dissertação sobre as leis dos pobres), em que se lê o seguinte a propósito de como lidar com a pobreza: "A fome amansará os animais mais ferozes, ela ensinará decência e civilidade, obediência e sujeição, ao mais bruto, ao mais obstinado e ao mais perverso [dos homens]" (Townsend, 1971, p. 27). ${ }^{7}$

Mas não são somente os homens pobres que deveriam, por isso, ser excluídos da educação escolar na Ilha. Também as mulheres. E Mandeville não se referia, aqui, às mulheres pobres, mas às mulheres sim-

${ }^{7}$ É minha a tradução do inglês. plesmente, as quais, segundo ele, deviam restringir-se ao mundo da costura e do governo da casa. Ele não deixa de reconhecer que são numerosos os exemplos de mulheres que se destacaram nas ciências e até na arte da guerra. Entende, porém, que "isto não é razão para que se ensine a todas latim e grego ou então a disciplina militar, em lugar da costura e do governo da casa". E argumenta: "Não há falta entre nós nem de disposição nem de capacidade, e não há nem terra nem clima em que as criaturas humanas possam envaidecer-se de estar melhor formadas, interior e exteriormente, do que aquelas que esta Ilha geralmente produz” (Mandeville, 2001, p. 207).

$\mathrm{O}$ autor finaliza o documento dizendo que, se a Rússia tem muito menos homens instruídos do que o necessário, a Grã-Bretanha os tem em demasia (idem, ibidem, p. 215).

Mandeville costuma ser incluído entre as figuras das Luzes que iluminaram a Inglaterra do século XVIII. Mas, com certeza, tal enlightenment (esclarecimento) não era para o povo, para os pobres, para os trabalhadores. Nem para as mulheres!

$\mathrm{Na}$ literatura recente há duas avaliações até certo ponto discordantes quanto a Mandeville. A primeira é de Gertrude Himmelbarb (1988). A autora diz que, se fosse necessário escolher uma única obra para exemplificar a ética amoral, associal que Tawney critica, tal obra seria A fábula das abelhas, de Bernard Mandeville. O que chama a atenção na avaliação de Himmelbarb (1988, p. 40) é que, em sua opinião, A fábula das abelhas está longe de ser representativa de sua época, porquanto teria desagradado profundamente a seus contemporâneos, provocando ataques frenéticos e fazendo até com que o grande júri de Middlesex condenasse a obra como uma "calamidade pública".

Interpretação bem diferente faz o francês Philippe Sassier, o qual, referindo-se à França, começa reconhecendo que houve um esforço de instrução no século XVIII e oferece como exemplo uma declaração real de 1724, que mandara criar escolas em todas as paróquias, mas de resultados muito modestos. "Sobre este ponto, - diz o autor - a atitude 'esclarecida' de um Voltaire - que é na essência também aquela do 
seu século - é ilustrada por um dos seus modelos de cinismo, o inglês Mandeville (1670-1733)". E acrescenta logo adiante: "As considerações deste inglês são o melhor resumo [...] do cuidado pedagógico da repressão na França em relação aos pobres”. Referese a seguir ao pensamento de outra figura de grande influência na França no que concerne à educação: "La Chalotais (1763), em seu Essai d'éducation nationale ou plan d'études pour la jeunesse (1763), fixa com muita precisão os limites: ' $\mathrm{O}$ bem da sociedade exige que os conhecimentos do povo não se estendam para além de suas ocupações"” (Sassier, 1990, p. 140). ${ }^{8}$ É interessante que, em outra passagem, Sassier diz que Voltaire, na França, às vezes copiava Mandeville ao pé da letra [trait pour trait]. (idem, ibidem, p. 144). Essa citação, extraída da obra de La Chalotais, também soa quase que textualmente a Mandeville. Considero mais plausível a interpretação de Sassier. Seria um grande equívoco subestimar a influência de Mandeville pelo simples fato de que poucos seguidores têm coragem de se declarar tributários de suas ideias.

\section{Adam Smith (1723-1790): um mínimo de instrução para todos}

Pouco mais de meio século separa a obra A riqueza das nações, de Adam Smith (1776), do texto de Mandeville sobre as Escolas de Caridade (1723). Mas algo muito importante separa esses dois momentos: o desencadear da Revolução Industrial. Junto com isso e por isso, se a atenção de Mandeville se dirigia antes para a arte de "manejar" a pobreza, Smith volta-se para o entendimento da explosão de riqueza (nacional) que de repente surpreende a Inglaterra. O título completo de sua obra é esclarecedor da nova situação: Inquérito sobre a natureza e as causas da riqueza das nações.

É um risco tentar confrontar Smith com Mandeville. A ênfase nas semelhanças pode levar a que se ignorem as diferenças. $\mathrm{O}$ realce das diferenças pode fazer esquecer as parecenças entre os dois liberais e,

${ }^{8}$ É minha a tradução do francês. ao mesmo tempo, entre as duas figuras do enlightenment anglo-escocês do século XVIII. Um fato que surpreende: nos dois longos volumes de sua obra, Smith não faz nenhuma referência a Mandeville, o que pode ser conferido no minucioso índice da edição da Fundação Calouste Gulbenkian (Smith, 1987, 1989). Não pegava bem fazer referência a Mandeville? Se foi por isso, algo semelhante aconteceria no mesmo país cerca de um século mais tarde: a tese de Herbert Spencer da "sobrevivência do mais apto" aplicada à espécie humana passaria à história associada a um nome mais "respeitável", o de Charles Darwin, donde a expressão equivocada de darwinismo social, em vez de spencerismo social.

Quem foi Adam Smith? Um expoente do iluminismo escocês; um dos principais economistas clássicos; o formulador do liberalismo econômico; segundo alguns (ou muitos), pai da nova ciência denominada Economia Política. Vou iniciar por dois pontos de proximidade ou ligação com Mandeville.

O primeiro diz respeito à teoria da divisão do trabalho. Smith inicia o primeiro capítulo de A riqueza das nações colocando na divisão do trabalho o fundamento da enorme expansão do poder produtivo do trabalho: "O maior acréscimo dos poderes produtivos do trabalho e grande parte da perícia, destreza e bom senso com que ele é em qualquer parte dirigido, ou aplicado, parecem ter sido os efeitos da divisão do trabalho" (1987, p. 77). Como já disse, Smith não se refere a Mandeville nesta parte. Mas qualquer pessoa que conheça as duas obras acaba fazendo a relação entre os dois autores. ${ }^{9}$

Se aqui se insiste na parecença entre Smith e Mandeville no que se refere à teoria da divisão do trabalho, é para poder realçar aquilo que separa o primeiro do segundo, que é de fundamental importância

${ }^{9}$ Na edição portuguesa, os tradutores observam que a expressão “divisão do trabalho” não era de uso corrente e que sua presença na obra de Smith "é provavelmente devida a um trecho da Fábula das abelhas, de Mandeville, parte II (1929), diálogo VI)" (in Smith, 1987, p. 77, nota 1). A comparação dos dois textos sugere essa interpretação. 
para compreender a mudança de postura, de um para outro, quanto à educação do povo (dos trabalhadores). Encontra-se em Smith igual ênfase, senão maior, na importância da divisão do trabalho. Smith substitui o exemplo da divisão do trabalho na fabricação de relógios pela divisão encontrada numa fábrica de alfinetes, com efeito semelhante na produção. Mas, se até aqui se parecia, a partir daqui Smith se diferencia e se afasta de Mandeville. Afinal, como reconhece Marx (seu maior crítico), Adam Smith fez ciência, tornou-se um clássico. A admiração pelos benefícios da divisão do trabalho não o cegou em relação aos malefícios que advinham ou poderiam advir da aplicação desse mesmo princípio. A citação é longa, mas fundamental para ressaltar a importância que Smith atribuía à educação. Diz ele no longo texto em que trata "Da despesa das instituições para a educação da juventude":

No progresso da divisão do trabalho a ocupação da enorme maioria dos que vivem do trabalho, isto é, a maior parte das pessoas, está confinada a algumas operações muito simples, frequentemente uma ou duas. Mas o desenvolvimento intelectual da maior parte das pessoas é necessariamente formado através desses empregos vulgares. O homem que passa toda a sua vida a executar algumas operações simples, cujos efeitos são sempre os mesmos, ou quase, não tem ocasião de exercitar a sua capacidade intelectual ou a sua habilidade de encontrar expedientes para afastar as dificuldades que nunca ocorrem. Perde naturalmente, portanto, o hábito desse exercício e torna-se geralmente tão estúpido e ignorante quanto é possível conceber-se numa criatura humana. O torpor do seu raciocínio torna-se não só incapaz de saborear ou tomar parte de qualquer conversa racional como também de conceber qualquer sentimento generoso, nobre ou terno, e, por consequência, até incapaz de formar qualquer julgamento sensato no que diz respeito a muitos dos deveres da vida privada. Dos grandes e mais vastos interesses do seu país é completamente incapaz de julgar; e a menos que haja um esforço muito particular para o modificar, é igualmente incapaz de defender o seu país numa guerra. [...] A destreza que possui no seu ofício particular parece, deste modo, ser adquirida à custa das suas virtudes intelectuais, sociais e marciais. (Smith, 1989, p. 416-417, grifo meu)
Até aqui, a diferença de Smith em relação a Mandeville pode resumir-se no seguinte: na sensibilidade que permite a Smith identificar e na postura ética que lhe faculta avaliar como um mal, como uma afronta a criaturas humanas o estado de estupidez e ignorância que geralmente acaba afetando os trabalhadores submetidos a esse "progresso da divisão do trabalho". Note-se: para Mandeville, esse estado de ignorância e estupidez das massas era condição de ordem e paz em qualquer reino e, como tal, devia ser preservado.

É na sequência da citação acima que aparece o elemento principal de distanciamento de Smith em relação a Mandeville: "Mas em toda a sociedade melhorada e civilizada é este o estado [de estupidez e ignorância] em que os trabalhadores pobres, ou seja, a maioria da população, cai necessariamente, a menos que o governo faça alguma coisa para impedi-lo" (Smith, 1989, p. 417, grifo meu). É surpreendente: Smith manifesta aqui uma posição favorável à intervenção do Estado em favor da "maioria da população", posição esta diametralmente oposta à de Mandeville. E o mais interessante é que esse elemento está na contramão dos próprios princípios smithianos da liberdade natural e da não-intervenção do Estado na economia. É possível que a última passagem citada não conste nas edições de A riqueza das nações utilizadas pelos espadachins do neoliberalismo que querem fundamentar em Smith o pretendido Estado mínimo ou do laissez-faire!

Com isso, pode-se passar ao segundo ponto de comparação entre Smith e Mandeville - a doutrina do papel do Estado ou o princípio da não-intervenção. Seria correto dizer, como querem alguns, que Smith é o formulador da doutrina do laissez-faire? A pergunta não pode ser respondida simplesmente com um sim ou um não. É necessário proceder por partes.

Smith notabilizou-se, entre outros motivos, pela aplicação dos princípios do liberalismo ao campo econômico, o que o levou a ser reconhecido como o formulador do liberalismo econômico. Ele afirma, por exemplo, que existem "taxas naturais de salários, lucro e renda” (Smith, 1987, p. 159); que o ajuste entre oferta e procura também se dá naturalmente (idem, ibidem, 
p. 162, por exemplo); que, para isso e por isso, é necessário que haja "completa liberdade" (idem, ibidem, passim). Para ele, as desigualdades existentes resultam, sim, da natureza das próprias utilizações do trabalho e do capital (idem, ibidem, p. 233-262); mas se devem também e principalmente à política da Europa "que em lado algum deixa perfeita liberdade às coisas” (idem, ibidem, p. 232) e que, "não permitindo que vigore essa liberdade total, dá origem a desigualdades muito mais importantes” (idem, ibidem, p. 263-304).

A formulação smithiana do liberalismo econômico se desdobra em três partes ou princípios. Tem-se, primeiro, o princípio fundamental do liberalismo econômico, denominado por Smith sistema da liberdade natural, o que equivale a dizer sistema da livre concorrência (Smith, 1989, p. 284).

O segundo princípio decorre do primeiro: se o indivíduo é portador de liberdade perfeita natural, ao Estado incumbe o dever de respeitar essa liberdade, de não intervir nessa ordem natural da economia (idem, ibidem, p. 284).

Firmados os princípios da liberdade natural do homem e da não-interferência do Estado, terreno em que se parece com Mandeville, Smith prossegue definindo o que chama de atribuições ou deveres do soberano, ponto em que mais uma vez se afasta de Mandeville, de modo particular no que se refere à educação dos trabalhadores. A ênfase dada aos princípios da liberdade natural e da não-interferência do Estado pareceria reforçada pela afirmação de que ao Estado restam apenas três deveres a cumprir, o que poderia ser entendido como fundando a doutrina neoliberal do Estado mínimo. No entanto, é preciso ter presente que o autor avalia esses mesmos três deveres como sendo deveres de grande importância, dedicando-lhes, no Livro V, quase 200 páginas, em que aborda sucessivamente as questões das despesas do Soberano (do Estado) com a defesa, com a Justiça, com os serviços públicos e as instituições públicas, inclusive as de educação, e finalmente com o sustento da dignidade do soberano (idem, ibidem, p. 284-285).

É verdade que o destaque dado por Smith à questão do papel do Estado acabaria por diluir-se algumas décadas mais tarde, especialmente com David Ricardo, como bem observa Hollander a propósito do que denomina "esfera de intervenção legítima do governo":

\begin{abstract}
Ricardo prestou muito menos atenção a esta questão do que
Adam Smith e J. B. Say [...]. Ricardo, obviamente, admitia que era legítimo, em certo sentido, que o governo proporcionasse ao menos alguns serviços, mesmo que fossem ‘improdutivos', porque considerava o gravame fiscal um mal necessário, mas nunca proporcionou, acerca do que pensava exatamente sobre essa questão, indicação alguma comparável às exposições de Smith sobre "defesa, justiça e obras públicas”. (Hollander, 1988, p. 482-485, grifos do original)
\end{abstract}

Mas, retornando a Smith, o que propõe ele sobre educação? Por quê? Para ele, "A educação da gente comum, numa sociedade comercial, requer talvez mais a atenção do [poder] público do que a educação das pessoas de posição e fortuna”. Estas últimas, esclarece Smith, geralmente completam 18 ou 19 anos "antes de entrar para o negócio particular, profissão ou ofício através do qual pretendem distinguir-se neste mundo”. Diferente, porém, é a situação da gente comum, que tem pouco tempo para dedicar à educação. "Os seus pais” - esclarece Smith - “mal podem mantê-los mesmo durante a infância. Logo que podem trabalhar, têm que arranjar qualquer trabalho com o qual garantir sua subsistência”. O conteúdo principal da educação da gente comum deve compreender "as partes fundamentais da educação: ler, escrever e contar". Junto com isso, em vez de "ligeiras noções de latim", aos filhos da gente comum deveriam ser ensinadas também "as partes mais fundamentais da geometria e da mecânica” (Smith, 1989, p. 419-421).

Se Mandeville se ocupava do manejo da pobreza, Smith ocupava-se da explicação da riqueza - da riqueza (nacional) nunca vista antes na Inglaterra, e das novas demandas de instrução que o processo econômico em curso colocava. Por isso, chegou a admitir que o poder público possa "facilitar, encorajar, e mesmo impor a necessidade da aquisição dessas partes mais essenciais da educação ao conjunto da população" (idem, ibidem, p. 421). 
Marx fez uma observação de grande interesse em relação a Smith. Disse que este, para evitar a degeneração completa do povo em geral oriunda da divisão do trabalho, "recomenda o ensino popular pelo Estado, embora em doses prudentemente homeopáticas" (Marx, 1998, p. 418). Sem dúvida, apenas em doses homeopáticas. No entanto, Smith representa uma posição liberal bastante avançada para a época (início do último quartel do século XVIII), o que foi evidenciado por outro fato lembrado pelo mesmo Marx. Relatou este que G. Garnier, ao traduzir a obra de Smith para a língua francesa, nesse ponto discordava do autor traduzido, por entender que a instrução popular contrariava as leis da divisão do trabalho e que adotá-la equivaleria a proscrever todo o sistema social francês (Marx, 1998, p. 418).

Diferentemente de Mandevillle, Smith ressaltava o fato de que, na Escócia, a criação de escolas paroquiais "ensinou a ler a quase totalidade da gente comum, e uma grande percentagem a escrever e contar”. E acrescentava que, embora em menor escala, as escolas de caridade tiveram "efeitos do mesmo gênero" também na Inglaterra (Smith, 1989, p. 421).

Quanto às mulheres, Smith limitou-se a constatar que "Não há instituições públicas para a educação das mulheres", sendo-lhes apenas ensinado "aquilo que os seus pais ou tutores julgam necessário ou útil à educação, e nada mais” (idem, ibidem, p. 415-416). Pouco avanço, nessa parte (metade da população!), em relação à posição de Mandeville. Era necessário esperar pela Revolução Francesa e, com ela, por sucessivas manifestações, como as de Olympe de Gouges em 1991 (Gouges, 1993, p. 185-196), de Mary Wollstonecraft em 1792 (1983) e do Marquês de Condorcet (1790 a 1793), em favor da igualdade das mulheres em relação aos homens, inclusive em assuntos de educação.

\section{Marquês de Condorcet (1747-1794): instrução comum, universal, pública, gratuita, obrigatória}

Foram consideradas até aqui duas posições do liberalismo frente à educação do povo: a de Bernard
Mandeville, na Inglaterra do primeiro quartel do século XVIII, e a do escocês Adam Smith, no início do último quartel do século XVIII. A terceira posição liberal, a ser agora analisada, é a do Marques de Condorcet (Jean-Antoine-Nicolas Caritat), conhecido também como o último filósofo das Luzes e o principal teórico da educação republicana.

Este terceiro momento foi muito bem analisado por Eliane Marta Santos Teixeira Lopes em seu estudo Origens da educação pública - a instrução na Revolução burguesa do século XVIII (1981). Segundo a autora: "A unanimidade dos três estados em relação à necessidade de reforma do aparelho escolar e a ausência de antagonismos entre seus aspectos mais essenciais possibilitaram e obrigaram a Revolução a ter a publicização da instrução constantemente na pauta de suas discussões”. No entanto, o consenso sobre a instrução pública terminava aí, como esclarece a autora: "Sua adjetivação, isto é, se obrigatória ou não, se laica ou não, se universal ou não, se gratuita ou não, vai depender do jogo de forças políticas, sociais e econômicas em cada momento da Revolução e do grupo que assume o poder" (Lopes, 1981, p. 60).

Toma-se como ponto de partida a opinião de Coutel e Kintzler (1994, p. 6), de que é a Condorcet que se deve "a teoria mais completa e mais moderna da escola republicana”. A ideia que se sustenta aqui é que ele se situa, quanto à instrução pública, no pólo oposto à posição de Mandeville, com grandes avanços inclusive em relação a Adam Smith. É claro que, como Mandeville e Smith, também Condorcet se situa dentro do pensamento liberal que instrumentou teórica e ideologicamente as revoluções burguesas, desde a Revolução Gloriosa de 1688 na Inglaterra até a Independência norte-americana em 1776, a Revolução Industrial na segunda metade do século XVIII na Inglaterra, a Revolução Francesa no final do século XVIII e a Revolução Burguesa em 1848, também na França.

Condorcet distinguira-se ainda muito jovem como matemático, ingressando aos 26 anos na Academia de Ciências. Quando em 1789 estourou a Revolução Francesa, ele foi um dos últimos sobreviventes 
autênticos do espírito das luzes. Em seu projeto de Declaração dos Direitos dos Homens, de fevereiro de 1789, ele se assumiu como tal quando disse que a sua proposta de declaração foi extraída de uma obra mais longa, em que ele "tinha ensaiado traçar uma exposição dos direitos dos homens tão completa quanto as minhas luzes mo puderam permitir” (Rials, 1988, p. 547). Seu liberalismo é atestado logo no início da sua proposta de declaração, em que diz que os direitos dos homens podem reduzir-se à segurança da pessoa, à liberdade da pessoa, à segurança da propriedade, à liberdade da propriedade e à igualdade entre os homens (Rials, 1988, p. 547). Mas há uma diferença essencial que distingue e até opõe o pensamento de Condorcet ao dos outros dois autores. Tanto o pensamento de Mandeville como o de Adam Smith estão embasados radicalmente no princípio burguês da liberdade. O pensamento de Condorcet se assenta sobre o princípio, também burguês-revolucionário, da igualdade. Isso faz muita diferença. A luta pelo direito à educação, assim como pelos demais direitos sociais, andou sempre fortemente apoiada no princípio da igualdade. Essa concepção igualitária aparece com clareza, em toda a radicalidade e extensão possíveis dentro do horizonte do projeto burguês na obra mais conhecida do autor, intitulada Esboço de um quadro histórico dos progressos do espírito humano, escrita em 1793, meses antes de sua prisão, e publicada no mesmo ano, meses depois de sua morte. Nela se lê: "Nossas esperanças sobre os destinos futuros da espécie humana podem se reduzir a estas três questões: a destruição da desigualdade entre as nações; os progressos da igualdade em um mesmo povo; enfim, o aperfeiçoamento real do homem" (Condorcet, 1993, p. 176-177).

Em setembro de 1791, Condorcet foi eleito deputado de Paris à Assembleia Legislativa e tornou-se membro do Comitê de Instrução Pública encarregado de propor a reforma das instituições escolares. Em 1792, apresentou, em nome do Comitê, o plano educacional justamente no momento em que a França declarava guerra à Áustria, fato que trunca mais uma vez, nos primeiros anos da Revolução, a aprovação de um projeto de reforma do ensino. Mais uma vez, porque coisa semelhante acabara de acontecer com o Relatório... de Talleyrand-Perigord (1791), o qual continha ideias bastante próximas àquelas que seriam defendidas por Condorcet.

Truncado o caminho ao projeto de Talleyrand, passou logo a destacar-se a participação de Condorcet, recém-eleito. Suas ideias sobre a instrução pública podem ser aferidas principalmente em três obras suas: Cinq memoires sur l'instruction publique (Cinco memórias sobre a instrução pública), de 1791 (Condorcet, 1994); Rapport et projet de décret relatif à l'organization de l'instruction publique (Relatório e projeto de decreto sobre a organização da instrução pública), de abril de 1792 (Condorcet, 1792) e Esquisse d'um tableau historique des progrès de l'esprit humain (Esboço de um quadro histórico dos progressos do espírito humano) (Condorcet, 1993), escrito em 1793 e publicado após sua morte graças ao empenho de Mme. de Condorcet. Além disso, embora tratando do direito de cidadania e não do direito à educação, não há como não considerar o texto Sur l'admission des femmes au droit de cité (Sobre a admissão das mulheres ao direito de cidadania), publicado em 1790.

Como parlamentar, Condorcet esteve ligado à Gironda, que, em 1793, durante o Terror, veria muitos de seus líderes mandados à guilhotina. No último capítulo de seu Esboço..., há uma passagem que sintetiza o pensamento do autor sobre a necessidade e a possibilidade real de instrução da "massa inteira do povo" e sobre o poder libertador da instrução:

\footnotetext{
Mostraremos que, por uma escolha feliz, tanto dos próprios conhecimentos quanto dos métodos de ensiná-los, pode-se instruir a massa inteira de um povo com tudo aquilo que cada homem precisa saber para a economia doméstica, para a administração de seus negócios, para o livre desenvolvimento de sua indústria e de suas faculdades; para conhecer seus direitos e exercê-los; para ser instruído sobre seus deveres, para poder cumpri-los bem; para julgar suas ações e aquelas dos outros segundo suas próprias luzes, e não ser alheio a nenhum dos sentimentos elevados ou delicados que honram a natureza humana; para não depender cegamente daqueles a quem é obrigado a confiar o cuidado de seus
} 
negócios ou o exercício de seus direitos, para estar em condições de escolhê-los e vigiá-los, para não ser mais a vítima desses erros populares que atormentam a vida com temores supersticiosos e esperanças quiméricas; para defender-se contra os prejuízos exclusivamente com as forças da razão, para escapar do prestígio do charlatanismo, que estenderia armadilhas à sua fortuna, à sua saúde, à liberdade de suas opiniões e de sua consciência, sob pretexto de enriquecê-lo, de curá-lo ou de salvá-lo”. (Condorcet, 1993, p. 184-185)

Enfim, instruir a massa inteira do povo com tudo aquilo que cada homem precisa saber. Para o autor, preocupado com a desigualdade, "a instrução bem dirigida corrige a desigualdade natural das faculdades, em lugar de fortalecê-la” (idem, ibidem, p. 186).

Mas talvez o texto mais importante, do ponto de vista da concepção de instrução pública, seja o Premier memoire, de 1791, que no ano seguinte passaria a integrar a obra Cinq mémoires... mencionada antes. Já no primeiro princípio Condorcet se contrapõe a Mandeville e vai além de Smith, porquanto vê a instrução pública como um dever da sociedade (do Estado) em relação ao povo, aos cidadãos: "A sociedade deve ao povo uma instrução pública". E deve-a: "1. Como um meio de tornar real a igualdade dos direitos. [...] $2^{\circ}$. Para diminuir a desigualdade que nasce da diferença de sentimentos morais. [...] $3^{\circ}$. Para aumentar na sociedade a massa de luzes úteis” (Condorcet, ${ }^{10} 1791$, p. 18).

O segundo princípio sustenta que "A sociedade deve igualmente uma instrução pública para as diversas profissões", de maneira a conseguir mais igualdade entre aqueles que a elas se dedicam; a torná-los todos igualmente mais úteis; a diminuir o perigo a que algumas dessas profissões expõem e a acelerar o seu progresso (idem, ibidem, p. 18-20).

O terceiro princípio tem a ver com o próprio progresso humano: "A sociedade deve ainda a instrução pública como meio de aperfeiçoar a espécie humana”. Condorcet propõe a organização da instrução pública

10 À exceção das citações de Esboço... (Condorcet, 1993), em todas as demais citações de Condorcet é minha a tradução do francês. em três níveis: a instrução comum, a instrução relativa às diferentes profissões e a instrução puramente científica - esta voltada para o aperfeiçoamento da espécie humana. É aqui que fica evidenciado o quanto a instrução comum proposta por Condorcet vai além daquela pensada por Smith. Para o autor, a instrução comum deve:

$1^{\circ}$ Ensinar a cada um, segundo o nível de sua capacidade e a duração do tempo de que dispõe, aquilo que é bom que todos os homens conheçam, qualquer que seja a sua profissão e o seu gosto;

$2^{\circ}$ Assegurar um meio de conhecer as potencialidades particulares de cada pessoa, a fim de poder tirar daí vantagem geral;

$3^{\circ}$ Preparar os alunos para os conhecimentos exigidos pela profissão a que se destinem”. (idem, ibidem, p. 20-28)

No quarto ponto, mais que um princípio, tem-se uma exposição dos "motivos para que se estabeleçam mais níveis na instrução comum”.

O quinto princípio sustenta que "A educação pública deve restringir-se à instrução” (idem, ibidem, p. 33), o que vale não só para as crianças, mas também para a educação dos adultos:

\footnotetext{
O que dissemos desta parte da instrução destinada às primeiras séries se estende igualmente àquela que deve abraçar o resto da vida. Ela não deve ter por objeto propagar tais ou quais opiniões, enraizar nos espíritos princípios úteis a certas opiniões, mas instruir os homens a respeito dos fatos que lhes importa conhecer, colocar sob seus olhos as discussões que interessam aos seus direitos ou à sua felicidade, $\mathrm{e}$ oferecer-lhes os recursos necessários para que eles possam decidir por si mesmos. (idem, ibidem, p. 42)
}

Neste ponto o autor passa a se referir explicitamente à instrução a ser proporcionada às mulheres. Como sempre se referira a homens e cidadãos, a expectativa era de que o autor viesse agora em defesa da instrução pública também para as mulheres. Não. Simplesmente defendeu que "A instrução deve ser $a$ mesma para as mulheres e para os homens” (idem, 
ibidem, p. 45). Na sequência, Condorcet reservou todo o sexto princípio à questão da instrução pública para as mulheres. "É necessário - disse ele - que as mulheres partilhem da instrução dada aos homens” (idem, ibidem, p. 46). Também nesse ponto Condorcet mantém posição diametralmente oposta à de Mandeville. Quando este dizia que a Grã-Bretanha tinha homens instruídos em excesso, estava pensando nos homens apenas, sem considerar as mulheres. Como já se disse, Mandeville sustentava que as mulheres deviam ocupar-se da costura e do governo da casa (Mandeville, 2001, p. 207).

Para Condorcet, as desigualdades resultam de três causas. Primeiro, da desigualdade de riqueza; segundo, da "desigualdade de estado", ou seja, da desigualdade entre aquele que pode transmitir à família os meios de subsistência e aquele para quem esses meios dependem da duração de sua vida, ou antes, daquela parte de sua vida em que ele é capaz de trabalhar; terceiro, da desigualdade de instrução (Condorcet, 1993, p. 182). A conquista da igualdade, portanto, passa necessariamente pela igualdade de instrução. Em Condorcet, o princípio da igualdade aplica-se a todo o povo, incluídas explicitamente também as mulheres. O autor não deixa dúvida nesse ponto ao dizer que "entre os progressos do espírito humano mais importantes para a felicidade geral, devemos incluir a destruição total dos preconceitos que estabeleceram entre os dois sexos uma desigualdade funesta àquele mesmo que ela favorece”. ${ }^{11} \mathrm{E}$ acrescenta que em vão se buscariam motivos para justificar essa desigualdade nas diferenças da organização física dos sexos, na forma da inteligência ou na sensibilidade moral. "Essa desigualdade - disse ele - só teve por origem o abuso da força, e foi em vão que depois se tentou desculpá-la por sofismas" (Condorcet, 1993, p. 195).

A impressão que se tem com a leitura da citação do Esquisse é que Condorcet já trabalhava de algu-

${ }^{11}$ É minha a tradução desta citação. Entendo que o termo préjugés (Condorcet, 1970, p. 211) deva ser traduzido por “preconceitos” e não por "prejuízos”, como foi na versão em português de 1993, p. 195. ma forma com o conceito de gênero, embora não, obviamente, com o termo gênero. Pelo menos com o conceito de gênero mais comum nas ciências sociais, como representando o aspecto social das relações entre os sexos, por oposição ao conceito biológico de sexo (Walby, 1996, p. 332-335). Com efeito, logo no primeiro parágrafo do Rapport et Project, fica estabelecido que o que se propõe é uma instrução nacional, universal, pública, que se constitui num dever do Estado, assentada sobre o princípio da igualdade e voltada para o estabelecimento de uma igualdade de fato entre os cidadãos, oferecida a todos os indivíduos da espécie humana, o que deve ser entendido como uma educação livre de qualquer tipo de discriminação - de religião, de sexo, de cor ou outra (Condorcet, 1792, p. 2). Isso já havia sido sustentado anteriormente no documento Sobre a admissão das mulheres ao direito de cidadania:

\begin{abstract}
Oferecer a todos os indivíduos da espécie humana os meios de prover as suas necessidades, de assegurar seu bem-estar, de conhecer e exercer seus direitos, de entender e cumprir seus deveres; assegurar a cada um deles a facilidade de aperfeiçoar sua habilidade, de habilitar-se para as funções sociais para as quais venha a ser chamado, de desenvolver toda a extensão dos talentos que recebeu da natureza, e por esse meio estabelecer entre os cidadãos uma igualdade de fato e tornar real a igualdade política reconhecida pela lei. Tal deve ser o primeiro objetivo da instrução nacional; e, sob este ponto de vista, ela é para o poder público um dever de justiça. (Condorcet, 1790, p. 2)
\end{abstract}

Na sequência do que foi dito, o plano distingue cinco níveis de instrução: escolas primárias, escolas secundárias, institutos, liceus e sociedade nacional das ciências e artes; nos quatro primeiros níveis o ensino deverá ser totalmente gratuito. Vale esclarecer que o que o plano prevê como ensino a ser ministrado nas escolas primárias é de caráter universal:

\footnotetext{
Nas escolas primárias ensina-se aquilo que é necessário a cada indivíduo para se conduzir a si mesmo e usufruir da plenitude de seus direitos. Essa instrução será suficiente
} 
até para aqueles que aproveitarão das lições destinadas aos homens para habilitá-los às funções públicas mais simples, às quais é bom que todo cidadão possa ser chamado, como aquela de jurado, de oficial municipal. Todo conjunto de casas que reúna quatrocentos habitantes terá uma escola e um mestre. [...] Estes diversos ensinamentos serão distribuídos em quatro anos, sendo que cada um deve ocupar por um ano as crianças de um mesmo nível. (idem, ibidem, p. 3)

Possivelmente como resultado de negociação dentro do já referido Comitê de Instrução Pública, o plano admite a iniciativa privada, "podendo cada cidadão criar livremente estabelecimentos de instrução”. Por último, o plano diz que, numa constituição fundada sobre a igualdade, não se deve temer que uma sociedade de homens esclarecidos venha a assumir facilmente esse espírito de corporação tão perigoso, mas tão natural num tempo em que tudo era privilégio (idem, ibidem, p. 14).

Na França, as ideias de Condorcet teriam que esperar quase um século, até Jules Ferry, para serem aceitas e transformadas em normas legais, justamente na década de 1870, quando, no Brasil, um país sem escolas, acender-se-ia o debate sobre a questão do voto dos analfabetos.

\section{O que tudo isto tem a ver com o Brasil?}

Tudo isto para dizer que não há um único liberalismo, por mais que todos se pareçam. E também para dizer que não há uma única forma de relação entre liberalismo e educação. Neste trabalho foram examinados três autores que expressam três versões típicas do liberalismo europeu do século XVIII: o liberalismo de Mandeville, que teme a instrução do povo; o liberalismo de Smith, o qual, mesmo que em doses prudentemente homeopáticas, requer uma instrução mínima (ler, escrever e contar) para todos os trabalhadores; por fim, o liberalismo de Condorcet, que defende uma educação comum, universal, pública, gratuita e obrigatória. Fundamentado no princípio da igualdade de todos os seres humanos, Condorcet contrapõe-se a Mandeville e avança para além de
Smith, estes últimos fundamentando suas posições apenas no princípio da liberdade.

Escolhi para análise casos típicos do liberalismo do século XVIII. Seguiram-se várias outras versões, destacando-se, no século XX, o liberalismo keynesiano (do Estado do bem-estar) e o neoliberalismo (do Estado mínimo). Ocupei-me desses três tipos de liberalismo por entender que o confronto estabelecido entre eles pode constituir-se numa referência importante para o entendimento do tipo de liberalismo que vingou no Brasil Império, particularmente no momento da reforma eleitoral para introdução da eleição direta, reforma esta que acabou resultando na exclusão dos analfabetos do direito de voto (Lei Saraiva, de 1881). Mas referência também para entender o que se passa hoje no país.

Retornando à questão levantada no início, penso que agora se pode convertê-la numa afirmação muito simples: Um país agrário, latifundiário, que, até quase o final do Império, teimosamente ainda se mantinha escravocrata, dificilmente poderia ter ido além de Mandeville em assunto de educação. É compreensível, portanto, que o liberalismo que alimentou o movimento da Independência (1822) e da Constituinte (1823), qualquer que fosse a sua fonte, acabasse sendo “traduzido” para a realidade brasileira de então. E isso não só em termos materiais, de realizações (no domínio da educação, por exemplo), mas também em termos das próprias ideias e princípios liberais. Tal tradução do liberalismo para as condições do Brasil foi muito bem expressa por Lúcia Maria Paschoal Guimarães, quando diz que, na América Portuguesa, uma vez conquistada a independência, “os homens que chegaram ao poder representavam os interesses de um grupo social ligado à propriedade da terra, à economia agroexportadora, dependente do trabalho escravo". E conclui: "O discurso liberal no Brasil, portanto, constituiu-se a partir dessa especificidade". Esclarece dizendo que, no caso brasileiro, a doutrina liberal foi, a um só tempo, "revolucionária", no que dizia respeito à emancipação política, e “conservadora”, quando o assunto era a manutenção da ordem interna vigente (Guimarães, 2001, p. 104). Entenda-se: a manutenção 
da economia e da sociedade brasileiras, fundadas em relações escravistas.

É ilustrativo, nesse sentido, o comentário de Dermeval Saviani a propósito do texto que ficou conhecido como Memória de Martim Francisco, em grande parte cópia dos Écrits sur l'instruction publique de Condorcet. O referido texto fora preparado para a reforma dos estudos na Capitania de São Paulo em 1816 e posteriormente reapresentado na Assembleia Constituinte em 1823. Na "tradução", a proposta de Condorcet foi duplamente apequenada: no plano das ideias e princípios, por ser esbulhada justamente naquilo que constituía seu elemento fundamental - o princípio da igualdade; no plano político-prático, por serem reduzidos para apenas três os quatro anos de instrução previstos para o primeiro grau de ensino. Diz Saviani:

De fato, em Cinq mémoires sur l'instruction publique, podemos encontrar as ideias básicas contidas na Memória de Martin Francisco. Mas o texto de Condorcet foi alterado, de modo que se ajustasse a um perfil ideológico algo distinto, esposado pelo autor brasileiro, conforme esclarece Querino Ribeiro: se Condorcet inicia seu ensaio se referindo à sociedade e aos cidadãos, Martim Francisco falava em soberanos e vassalos, e a palavra 'igualdade’, que aparece freqüentemente no texto de Condorcet, está inteiramente ausente na Memória de Martim Francisco (Ribeiro, 1945, p. 89). Observe-se também que, enquanto no plano de Condorcet a instrução de primeiro grau teria a duração de quatro anos, Martim Francisco justifica a fixação em três anos [...]. (Saviani, 2007, p. 120)

Mesmo assim “depurada”, nem o elevado prestígio de Martim Francisco, enquanto membro da "santíssima trindade” formada pelos três irmãos Andradas (idem, ibidem, p. 120, nota 5), conseguiu impedir que sua proposta fosse votada ao esquecimento. Com mais razão, decorrido mais de meio século, o regime monárquico negaria decididamente ouvidos às ideias do filho de Martim Francisco, José Bonifácio, o Moço, cuja posição no campo da educação se situava bem mais próxima da de Condorcet. A título de ilustração, comparo dois discursos em favor de duas causas relacionadas ao direito de cidadania: na França, em 1790, a argumentação de Condorcet em defesa do direito de cidadania (direito de voto) das mulheres; no Brasil, quase um século mais tarde, em 1879, a argumentação de José Bonifácio, o Moço, em defesa do voto dos analfabetos. No Brasil imperial, sequer se falava ainda em voto das mulheres! E muito pouco em instrução das mulheres!

Na França, em 1790, depois de responder àqueles que objetavam que as mulheres "não são jamais conduzidas por aquilo que se chama de razão” e que "obedecem antes ao seu sentimento do que à sua consciência", Condorcet ironizava:

\footnotetext{
Se se admitem contra as mulheres razões semelhantes, seria necessário também privar do direito de cidadania aquela parte do povo que, entregue a trabalhos sem folga, não pode nem adquirir luzes nem exercer a razão, e muito breve, passo a passo, não se permitiria serem cidadãos a não ser aos homens que tenham feito um curso de direito público (1790, p. 7).
}

Ironia semelhante é encontrada, quase um século mais tarde, na argumentação de José Bonifácio, o Moço, em defesa do voto dos analfabetos. Ele argumenta que, se para votar não basta querer e discernir; se é preciso condição especial de capacidade, esta lógica levaria a uma situação absurda assim descrita:

\footnotetext{
Excluís os analfabetos, porque não sabem ler e escrever; excluís os que não sabem ler e escrever, porque não sabem calcular; excluís os que não sabem calcular, porque não são doutores; excluís os que são doutores, porque há quem saiba mais do que eles (riso) (Brasil, Câmara, Anais, sessão de 28 maio 1879 , p. 432-433).
}

O discurso da maioria liberal da Câmara dos Deputados contra o voto dos analfabetos poderia parecer-se com as ideias de Adam Smith e até de John Stuart Mill. A realidade, porém (a generalizada falta de escolas para o povo), associava-o muito mais a Mandeville. As palavras de José Bonifácio, o Moço, 
ajudam a entender o que se acaba de dizer. Referindose particularmente à autoridade de Stuart Mill (18061873), tantas vezes invocado na Câmara nos debates em favor da exclusão dos analfabetos, diz:

\begin{abstract}
A opinião dos escritores citados nesta casa para sustentar a famosa exclusão [dos analfabetos do direito de voto] não tem o valor que se lhe empresta; porque parte do ensino obrigatório e gratuito assenta todo seu raciocínio na generalidade ou facilidade da instrução primária. No Brasil não raciocinariam do mesmo modo. Uma das províncias do Império em que a instrução está mais generalizada é o Rio de Janeiro. Pois bem, leia-se o relatório do ilustre Sr. Visconde de Prados e ver-se-á qual a distribuição das escolas e quais as facilidades que lá mesmo se encontram para aprender a ler e escrever. Há perímetro de tal extensão, em que os moradores das extremidades precisariam do dia inteiro para ir às escolas e voltar das apetecidas lições (Brasil. Câmara, Anais).
\end{abstract}

É claro que, a esta altura, preciso estar preparado para responder a uma objeção: o que tudo isso tem a ver com o Brasil de hoje? O Brasil foi historicamente e continua sendo o verdadeiro reino da vagareza em assuntos de escolarização e alfabetização do povo. Fechou o século XX com 17,6 milhões de analfabetos entre as pessoas de 10 anos ou mais, o que representa mais de duas vezes o número de analfabetos contados no Brasil nos censos de 1872 e 1890.

Independentemente de leis e discursos, o Brasil continua figurando entre os países de maior desigualdade social. Para José Murilo de Carvalho (2004, p. 207), as maiores dificuldades, hoje, na área social "têm a ver com a persistência das grandes desigualdades sociais que caracterizaram o país desde a independência, para não mencionar o período colonial". E ilustra: "Segundo relatório do Banco Mundial, era o país mais desigual do mundo em 1989”. As obras organizadas por Celi Scalon, Imagens da desigualdade (2004), e por Jessé Souza, A invisibilidade da desigualdade brasileira (2006) revelam, de vários ângulos, o quanto o Brasil está arredado do princípio da igualdade, senão no discurso, pelo menos nas práticas e nas condições sociais da população brasileira. Segundo Scalon (2004, p. 109), a análise das questões sociais no Brasil "deve levar em conta que este país tem na desigualdade a sua principal característica”. Souza (2006, p. 19), por sua vez, observa que seu interesse nuclear na organização do livro foi "mapear o tema da desigualdade e da sua legitimação e naturalização no Brasil contemporâneo em todas as suas manifestações principais”.

Em tais condições de desigualdade, não é de se estranhar que, justamente no momento em que encerro este texto, tenha que me defrontar com um discurso indignado contra a introdução da sociologia e filosofia no ensino médio, disciplinas que, segundo o autor, “acabam de ser impostas". Em sua opinião, isso levará os alunos a ter que aprender os ensinamentos de Marx, Engels, Rousseau, Durkheim e, talvez, de Sócrates e Hegel, em vez de "aprender coisas úteis e evoluir na vida”, seguindo os ensinamentos de Smith, Bentham e J. S. Mill (Ioschpe, 2008, p. 18). Faltou mencionar Mandeville: não ensinar aos trabalhadores mais do que o estritamente necessário (útil) para o exercício da profissão!

Em suma, no caso do Ensino Médio, hoje condição cada vez mais indispensável para acesso a qualquer ocupação, o ensino e a aprendizagem deveriam, na perspectiva mandevilliana, circunscrever-se às “coisas úteis" demandadas pelo mercado. Está aí $A$ fábula das abelhas em versão 2008! No entanto, como pegaria mal fazer referência a Mandeville, invoca-se a autoridade dos clássicos Adam Smith e Stuart Mill.

Para o ultraliberalismo de todos os tempos, inclusive para aquele que leva o nome de neoliberalismo, o liberal Condorcet e seu princípio da igualdade continuam cheirando a socialismo.

\section{Referências bibliográficas}

AMADO, Janaina; FIGUEIREDO, Luiz Carlos. Brasil 1500. Quarenta documentos. Brasília: Ed. Universidade de Brasília, São Paulo: Imprensa Oficial do Estado de São Paulo, 2001. p. 73-122. BRASIL. Câmara dos Deputados. Anais. Sessão de 28/05/1879. Disponível em: $<$ http://imagem.camara.gov.br/pesquisa_diario_basica.asp>. Acesso em: 29 jun. 2007.

CARVALHO, José Murilo de. Cidadania no Brasil: o longo caminho. 5. ed. Rio de Janeiro: Civilização Brasileira, 2004. 
CONDORCET, Jean Antoine Nicolas de Caritat, Marquês de. Esboço de um quadro histórico do progresso do espírito humano. Original francês de 1793. Campinas: Ed. UNICAMP, 1993.

Esquisse d'un tableau historique des progrès de l'esprit humain (1793-1794). Paris: Librairie Philosophique J. Vrin, 1970. Collection: Bibliotèques des textes philosophiques. Disponível em: <http://classiques.uqac.ca/classiques/condorcet/ esquisse_tableau_progres_hum/esquisse_tableau_hist.pdf $>$. Acesso em: 31 maio 2008.

Rapport sur l'organization générale de l'instruction publique. Présentation à l'Assemblée législative: 20 et 21 avril 1792. Assemblée Nationale - Grands moments d'éloquence parlamentaire - Condorcet (1792). Disponível em: $<$ http://www.assemblee-nationale.fr/histoire/7ed.asp > . Acesso em: 31 maio 2008. Sur l'admission des femmes au droit de cité. Journal de la Société de 1789, n. V, 3 juillet, 1790 (Facsimile). Disponível em: <http://oll.libertyfund.org./title/1014>. Acesso em: 5 abr. 2008. Cinq mémoires sur l'instruction publique, 1791. Paris: Garnier-Flammarion, 1994. Disponível em: <http://classiques.uqac.ca/classiques/condorcet/cinq_memoires_instruction/ Cinq_memoires_instr_pub.pdf>. Acesso em: 8 maio 2008.

Memoire sur l'instruction publique. Disponível em:

$<$ http://www.premiumwanadoo.com/jeunes-laiques/modules.ph $\mathrm{p}$ ?name $=$ News $\&$ file $=$ article $\&$ sid $=3>$. Acesso em: 8 maio 2008 .

Le projet de déclaration des doits de Condorcet (février 1789). In: RIALS, Stéphane. La déclaration des doits de l'homme e du citoyen. Paris: Hachette, 1988. p. 546-550.

COUTEL, Charles; KINTZLER, Catherine. Preséntation. In: CONDORCET, Marie Jean Antoine Nicolas de Caritat, Marquis de. Cinq mémoires sur l'instruction publique, 1791. Paris: Garnier-Flammarion, 1994. Disponível em: <http://classiques.uqac. ca/classiques/condorcet/cinq_memoires_instruction/Cinq_memoires_instr_pub.pdf $>$. Acesso em: 8 maio 2008.

GARANDEAU, Mikaël (Org.). Le liberalisme. Paris: Flammarion, 1998.

GOUGES, Olympe. La déclaration des doits de la femme e de la citoyenne. In: NOACK, Paul. Olympe de Gouges. Courtisane et militante des droits de la femme. S.1.: Ed. Fallois, 1993.

GUIMARÃES, Lucia Maria Paschoal. Liberalismo moderado: postulados ideológicos e práticas políticas no período regencial (1831-1837). In: GUIMARÃES, Lucia Maria Paschoal; PRADO, Maria Emilia (Orgs.). O liberalismo no Brasil imperial: origens, conceitos e prática. Rio de Janeiro: Revan/UERJ, 2001. p. 103-126.
HIMMELBARB, Gertrude. La idea de la pobreza. Inglaterra a principios de la era industrial. México: Fondo de Cultura Económica, 1988.

HOLANDA, Sérgio Buarque de. O Brasil Monárquico. V. 5 - Do Império à República. In: (Dir.). História geral da civilização brasileira. Rio de Janeiro/São Paulo: Difel, 1977.

HOLLANDER, Samuel. La economia de David Ricardo. México: Fondo de Cultura Económica, 1988.

IOSCHPE, Gustavo. A ditadura da vontade própria. Zero Hora, Porto Alegre, Geral, p. 18, 15 jun. 2008.

KAYE, F. B. Introducción. In: MANDEVILLE, Bernard. La fábula de las abejas o los vicios privados hacen la prosperidad pública. México: Fondo de Cultura Económica, 2001. p. viii-lxxvii.

LOPES, Eliana Marta Santos Teixeira. Origens da educação pública. A instrução na Revolução burguesa do século XVIII. São Paulo: Loyola, 1981.

MANDEVILLE, Bernard. La fábula de las abejas o los vicios privados hacen la prosperidad pública. Comentário crítico, histórico y explicativo de F. B. Kaye. Publicação original em inglês de 1705 a 1729. México: Fondo de Cultura Económica, 2001.

MARX, Karl. O capital. Crítica da economia política. II. 16. ed. Rio de Janeiro: Civilização Brasileira, 1998.

MOACYR, Primitivo. A instrução e o Imperio. Subsídios para a história da educação no Brasil. 1854-1889. V. 3. São Paulo: Nacional, 1938.

OLIVEIRA, Avelino da Rosa; GHIGGI, Gomercindo. John Locke. Alguns pensamentos acerca da educação. Cadernos de Educação, v. 8, n. 13, p. 147-171, 1999.

RIALS, Stéphane. La déclaration des doits de l'homme e du citoyen. Paris: Hachette, 1988. p. 546-550.

RIBEIRO, Renato Janine. A economia como mistério. Revista Cult, fev. 2004. Disponível em: <http://www.renatojanine.pro.br/ FiloPol/edonomia.html>. Acesso em: 23 maio 2008.

SASSIER, Philippe. Du bom usage des pauvres. Histoire d'un thème politique (XVI-XX siècle). Mesnil-sur-l'Estrée: Fayard, 1990.

SAVIANI, Dermeval. História das ideias pedagógicas no Brasil. Campinas: Autores Associados, 2007.

SCALON, Celi (Org.). Imagens da desigualdade. Belo Horizonte: Ed. UFMG; Rio de Janeiro: IUPERJ/FAPERJ, 2004.

SMITH, Adam. Inquérito sobre a natureza e as causas da riqueza das nações. V. 1. 2. ed. Original de 1776. Lisboa: Fundação Calouste Gulbenkian, 1987. 
. Inquérito sobre a natureza e as causas da riqueza das

nações. V. 2. 2. ed. Original de 1776. Lisboa: Fundação Calouste Gulbenkian, 1989.

SOUZA, Jessé (Org.). A invisibilidade da desigualdade brasileira. Belo Horizonte: Ed. UFMG, 2006.

TALLEYRAND-PERIGORD, Charles Maurice de. Ancien Evêque d'Autun. Rapport sur l'instruction publique fait ao nom du Comité de Constitution à l'Asemblée Nationale les 10, 11 et 19 septembre 1791. Disponível em: <http://pcombal.club.fr/rapport. html>. Acesso em: 8 maio 2008 .

TOWNSEND, Joseph. A dissertation on the poor laws. By a wellwisher to mankind. Berkeley: University of California Press, 1971. WALBY, Sylvia. Gênero. In: OUTHWAITE, William; BOTTOMORE, Tom. Dicionário do pensamento social no século XX. Rio de Janeiro: Jorge Zahar, 1996. p. 332-335.

WOLLSTONECRAFT, Mary. Vindication of the rights of woman. Repr. Harmondsworth/Middlesex: Pinguin Books, 1983.

ALCEU RAVANELLO FERRARO, doutor em ciências sociais pela Pontifícia Universidade Gregoriana, professor e coor- denador do Programa de Pós-Graduação em Educação do Centro Universitário La Salle (UNILASALLE, Canoas-RS). Ex-professor titular da Universidade Federal do Rio Grande do Sul (UFRGS), hoje aposentado. Publicações recentes: AANPEd, a pós-graduação, a pesquisa e a veiculação da produção intelectual na área da educação (Revista Brasileira de Educação, n. 30, p. 47-69, set./dez. 2005); Analfabetismo e níveis de letramento no Brasil: o que dizem os censos? (Educação e Sociedade, v. 23, n. 81, p. 21-47, dez. 2002); Gênero e alfabetização no Brasil. Caminhos para a pesquisa em sociologia da educação a partir de fontes estatísticas (In: PAIXÃO, Lea Pinheiro; ZAGO, Nadir (Orgs.). Sociologia da educação: pesquisa e realidade brasileira. Petrópolis: Vozes, 2007. p. 154-181). Pesquisa atual: "Gênero, raça e escolarização no Brasil: traçando a trajetória da relação", em desenvolvimento com o apoio do Conselho Nacional de Desenvolvimento Científico e Tecnológico (CNPq). Com base em determinação judicial, em 1992 o sobrenome do autor foi retificado, passando de Ferrari para Ferraro.E-mail: aferraro@unilasalle.edu.br

Recebido em agosto de 2008

Aprovado em abril de 2009 
Palabras-claves: trabajo docente; sindicalismo docente; profesionalidad docente; trabajadores de la educación; CTERA.

Maria da Graça Jacintho Setton

A socialização como fato social total: notas introdutórias sobre a teoria do habitus

O objetivo deste artigo é refletir sobre o processo de socialização segundo a perspectiva da sociologia da educação. Mais precisamente, pensar a teoria da socialização a partir de um ponto de vista relacional, articulando as principais agências educativas da atualidade. Para melhor compreender o fenômeno da socialização contemporânea, propõe-se pensar essa prática como um fato social total, isto é, uma prática social vivida por uma dinâmica processual a partir da troca de bens e mensagens simbólicos entre agências e agentes socializadores, que envolve simultaneamente todos os indivíduos com a tarefa de manter o contrato e o funcionamento da realidade social. Para desenvolver esse argumento, darse-á ênfase a duas teorias da ação que discutem o processo de socialização: a primeira se refere à teoria do habitus, de Pierre Bourdieu; a segunda, àquela desenvolvida por Bernard Lahire que, em uma interpretação particular e crítica a Bourdieu, propõe uma leitura contemporânea da socialização, cunhando a expressão homem plural.

Palavras-chave: fato social total; habitus; homem pural.

\section{Socialization as a total social fact:} introductory notes on the theory of habitus

The objective of this article is to reflect upon the process of socialization from the perspective of the sociology of education. More precisely, to discuss the theory of socialization starting from the relational point of view and articulating the chief current educational agencies. In order to understand better the phenomenon of contemporary socialization, we propose to consider this practice as a total social fact, that is, a social practice lived by a procedural dynamic based on an exchange of goods and symbolic messages between socializing agencies and agents which simultaneously involve all individuals in the task of maintaining the contract and the functioning of social reality. In order to develop this argument, we emphasize two theories of action which discuss the process of socialization: the first refers to Pierre Bourdieu's theory of habitus and the second to that developed by Bernard Lahire who, in a critical interpretation of Bourdieu, proposes a contemporary reading of socialization, coining the expression plural man.

Key words: total social fact; habitus; plural man.

\section{A socialización como hecho social} total: notas introductorias sobre la teoría del habitus

El objetivo de este artículo es reflexionar sobre el proceso de socialización según la perspectiva de la sociología de la educación. Pero precisamente, pensar la teoría de la socialización a partir de un punto de vista relacional, articulando las principales agencias de educación de la actualidad. Para mejor comprender el fenómeno de la socialización contemporánea, se propone pensar esa práctica como un hecho social total, esto es, una práctica social vivida por una dinámica procesal a partir del cambio de bienes y mensajes simbólicos entre agencias y agentes socializadores, que abarca simultáneamente todos los individuos con la tarea de mantener el contrato y el funcionamiento de la realidad social. Para el desarrollo de este argumento, se le dará énfasis a dos teorías de la acción que discuten el proceso de socialización: la primera se refiere a la teoría do habitus, de Pierre Bourdieu; la segunda, aquella dessarrollada por Bernard Lahire que, en una interpretación particular y crítica a Bourdieu, propone una lectura contemporánea de la socialización, acuñando la expresión hombre plural.

Palabras claves: hecho social total; habitus; hombre plural.

Alceu Ravanello Ferraro

Liberalismos e educação. Ou por que o Brasil não podia ir além de Mandeville

Este trabalho examina três autores que expressam versões típicas do liberalismo europeu do século XVIII: o liberalismo de Mandeville, que teme a instrução do povo; o liberalismo de Smith, o qual requer uma instrução mínima (ler, escrever e contar) para todos os trabalhadores; e o liberalismo de Condorcet, que defende uma educação comum, universal, pública, gratuita e obrigatória. Fundamentado no princípio da igualdade de todos os seres humanos, Condorcet contrapõese a Mandeville e avança para além de Smith, que fundamentam suas posições apenas no princípio da liberdade. A opção apoiou-se no pressuposto de que o confronto estabelecido entre eles poderia constituir-se em referência para o entendimento do tipo de liberalismo que vingou no Brasil Império, em especial no momento da reforma eleitoral de 1881, a qual, ao introduzir a eleição direta, determinou a exclusão dos analfabetos do direito de voto, mas é referência também para o entendimento do que se passa hoje no País.

Palavras-chave: liberalismo; Brasil; alfabetização; escolarização.

Liberalisms and education, or why Brazil could not go beyond Mandeville

This paper discusses three authors who express three typical versions 
of $18^{\text {th }}$ century European liberalism: Mandeville's liberalism, which fears the people's instruction; Smith's liberalism, which requires a minimal instruction (reading, writing and counting) for all workers; and Condorcet's liberalism, which advocates a common, universal, public, free and mandatory education. Based on the principle of the equality of all human beings, Condorcet opposes Mandeville and goes beyond Smith, as the latter base their positions only on the principle of freedom. The choice starts from the assumption that the confrontation that was established between them might be a benchmark to understand the kind of liberalism that prevailed in the Brazilian Empire, particularly at the time of the electoral reform (the so-called Saraiva Act of 1881) that introduced direct elections and eventually excluded the illiterate from the right to vote. But they could also serve as a benchmark to understand what occurs in Brazil today.

Key words: liberalism; Brazil; literacy; schooling.

Liberalismos y educación, o por qué Brasil no podía ir más allá de Mandeville

Este trabajo examina a tres autores que expresan versiones típicas del liberalismo europeo del siglo XVIII: el liberalismo de Mandeville, que teme a la instrucción del pueblo; el liberalismo de Smith, el cual requiere una instrucción mínima (leer, escribir y contar) para todos los trabajadores; y el liberalismo de Condorcet, que defiende una educación común, universal, pública, gratuita y obligatoria. Fundamentado en el principio de la igualdad de todos los seres humanos, Condorcet se contrapone a Mandeville y avanza para más allá de Smith, que fundamentan sus posiciones apenas en el principio de la libertad. La opción se apoyó en la suposición de que el confronto establecido entre ellos podría constituirse en referencia para el entendimiento del tipo de liberalismo que prosperó en Brasil Imperio, en especial en el momento de la reforma electoral de 1881, la cual, al introducir la elección directa, determinó la exclusión de los analfabetos del derecho de voto, mas es referencia también para el entendimiento de lo que pasa hoy en el País.

Palabras claves: liberalismo; Brasil; alfabetización; escolarización.

Lidia Mercedes Rodriguez

Educação de jovens e adultos na América Latina: políticas de melhoria ou de transformação; reflexões com vistas à VI CONFINTEA

Ainda não se consolidou uma proposta alternativa para incorporar as grandes massas aos processos educativos. Não obstante, os processos de abertura política que se verificam na América Latina nos últimos anos abrem espaço para a formulação de novos paradigmas. A disjuntiva é ceder às propostas liberalizantes da globalização, consolidando a educação como mercadoria, ou retomar o conceito freireano de educação, com vista a contribuir para a construção da cidadania e da participação. O desafio para a CONFINTEA VI é construir sínteses capazes de levar a consensos sobre conteúdos e métodos de educação de jovens e adultos, além de atender às urgências, encarando a educação não como custo ou investimento, mas como direito ou serviço, e promover a construção de espaços públicos nos quais se edifique a totalidade social com a especificidade de cada grupo, no contexto do multiculturalismo.

Palavras-chave: educação de jovens e adultos; novos paradigmas; multiculturalismo.
Adult and youth education in Latin America: policies of improvement or transformation; reflections with a view to CONFINTEA VI

Until now no alternative proposal for incorporating the masses into educational processes has been consolidated. However, the processes of political democratization which have been seen in Latin America in recent years have opened space for the elaboration of new paradigms. The disjunctive is either to give in to liberalizing proposals of globalization, consolidating education as a commodity, or to return to the Freirian concept of education with a view to contributing to the construction of citizenship and participation. The challenge for CONFINTEA VI is to construct syntheses capable of achieving consensus on contents and methods for adult and youth education in addition to attending to the urgencies, understanding education not as a cost or investment but as a right or service, and to promote the construction of public spaces in which the social totality is built on the specificity of each group in the context of multiculturalism.

Key words: adult and youth education; new paradigms; multiculturalism.

\section{Educación de adultos en América} Latina: políticas de mejora o de transformación; reflexiones en vistas a la CONFINTEA VI

Todavía no se ha consolidado una propuesta alternativa para incorporar a las grandes masas en los procesos educativos. Sin embargo, los procesos de apertura política que se están desarrollando en América Latina en los últimos años abren espacio para la formulación de nuevos paradigmas. La disyuntiva es ceder a las propuestas liberalizantes de la globalización, consolidando la educación como mercancía, o retomar el concepto 